\title{
Exploration of Flavonoids From Physcomitrella Patens for Determining Its Antimicrobial Potential
}

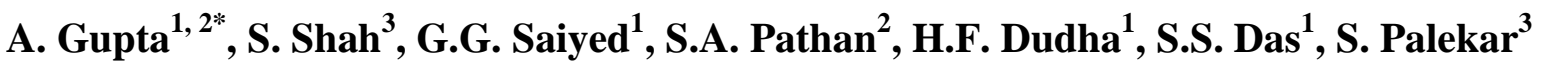 \\ ${ }^{1}$ Dep. of Biotechnology, School of Sciences, P.P. Savani University, Surat, India \\ ${ }^{2}$ Dep. of Microbiology, School of Sciences, P.P. Savani University, Surat, India \\ ${ }^{3}$ Dep. of Microbiology, Mrinmay diagnostic lab (MDL), Shaupuri Vyaparipeth Suvarna Hospital, Kolhapur \\ *Corresponding Author: amit.gupta@ppsu.ac.in, Tel.: +91-8308881506
}

Available online at: www.isroset.org

Accepted: 17/Aug/2018, Online: 30/Aug/ 2018

\begin{abstract}
Bryophytes (e.g. mosses) is one of the largest taxonomical group and also considered them as an important component of ecosystem. Traditionally, these mosses are widely used in the form of extract (primary/secondary metabolites) and showed immunopharmacological properties (e.g. for curing tuberculosis, pneumonia, neurasthenia and other illnesses) as well. The major primary components of mosses i.e. carbohydrates and secondary metabolites (e.g. flavonoids, terpenoids etc.) showing some immunopharmacological activity. Till date, composition and characterization of only few mosses has been studied in detail with respect to immunopharmacological applications. In the present study, extract the flavonoid from moss species which is identified through qualitative (lead acetate and thin layer chromatography, TLC) and determined its antimicrobial activity against various bacterial strains. The results showed the presence of flavonoids at higher concentration showing inhibitory action against various bacterial strains as compared to control. These studies which clearly indicates its antimicrobial activity. In short, these mosses are considered to be one of the most potent and attractive candidate for human health diseases.
\end{abstract}

Keywords - Bryophytes, primary, secondary, metabolites, immunopharmacological

\section{INTRODUCTION}

Bryophytes are one of the second largest group of terrestrial plants, which contained approximately 25,000 species. These bryophytes are also called as mosses which played an important role in ecological systems and is widely used in pharmacology, medicine and agriculture [1-4]. In contrast, these mosses are considered as tiny plants with a simple body plan and have no roots, flowers and seeds. Therefore, for a long time they were considered these mosses as simple organisms at the genetic level too. One of the most familiar example in moss i.e. Physcomitrella, small plant that has become an important biological tool in plant research [5-8]. The main reason is that it is so easy to inactivate (knock out) genes by using homologous recombination, so called reverse genetics. So, this moss is developed into an important model plant [5]. The main sequence of the Physcomitrella genome has been determined, which has further increased its value as a model organism [6-8]. Somehow, this is done only in yeast and mice but not in plants. In view of this, knocking out genes from plants makes it possible to figure out their functions by studying its biological properties that lack the gene $[9,10]$.
Mosses research has a long history with several important contributions to basic science. In contrast, these are included in between single-celled algae and complex seed plants. The major dominant part in moss development i.e. gametophytic (haploid) phase. These mosses should be grown in self-contained systems (e.g. Petri dishes, Erlenmeyer flasks or bioreactors in pure mineral media without any organic additions such as antibiotics, carbon sources or growth regulators) and these are worked under highly controlled environmental conditions [5-11]. As per the literature, these bryophytes are scarce especially reported in warm along with drier lowland areas but prolific is reported in higher mountain or hilly areas where temperatures are lower and humidity is higher [11, 12]. In this regard, one of the botanist Gerald Zotz, University of Oldenburg explained that survival of bryophytes showed some balancing act with respect to daytime during photosynthesis (intake of carbon) and through respiration (night-time loss of carbon). So, this type of balance is totally dependent on temperature and humidity [11-13]. Due to these features, scientists worked on these plants especially mosses in order to find out its biotechnological applications because of richness in a variety of biologically active compounds viz. terpenoids, phenols, glycosides and fatty acids [14]. One of the most familiar examples in case of flavonoids were reported in bryophytes. 
In 2017, Wang reported that higher flavonoid contents were observed at lower light levels as compared to those growing in full-sun. In view of this, flavonoid contents is observed especially epiphytic bryophytes were more as compared to aquatic bryophytes; flavonoid contents growing at lowlatitudes were more as compared to high-latitude individuals [15]. In view of this, flavonoid contents of bryophytes showed some connection with plant phylogeny $[14,15]$. In the present review, we focused on various bryophytes in detail that will widely open the door for the use of different bryophytes in plant biotechnology and to meet the demand of novel drug discovery.

\section{Methodology}

\section{Plant Material and growth conditions}

Strain of P. Physcomitrella patens was used throughout the studies. In this study, protonemata (seven day old) were grown on solid medium where di-ammonium tartrate $(5 \mathrm{mM})$ was added. Cultured the samples at $25{ }^{\circ} \mathrm{C}$ under continuous light through fluorescent tubes. Approximately $1 \mathrm{~g}$ of fresh weight of protonemal tissue was ground to a fine powder for extraction of flavonoid under liquid nitrogen using a precooled mortar and pestle.

\section{Extraction of flavonoid}

Take $1 \mathrm{~g}$ of moss species with $80 \%$ methanol $(50 \mathrm{ml})$ and reflux it for $2 \mathrm{~h}$ at $100^{\circ} \mathrm{C}$, filter by whatman filter paper and collect filtrate in separating funnel add $10 \mathrm{ml}$ ethyl acetate with $20 \mathrm{ml}$ distilled water, mix it properly. Then collect only upper layer of ethyl acetate and evaporate it. The dried extracts were dissolved in $2 \%$ dimethyl sulphoxide and phosphate buffer saline and vortex for $1 \mathrm{~min}$ were used (Fig.1) for further studies [16].

Qualitative analysis of flavonid:-To small quantity of sample, lead acetate solution was added. Formation of yellow precipitation showed the presence of flavonoids (Fig.2).

\section{Thin layer chromatography (TLC)}

Thin layer chromatography (TLC) was performed on the crude extract of ethanol using silica plate. Take small amount of crude sample of this extract [17-19]. In each case, $1 \mathrm{~cm}$ was measured from the base of the TLC plate, marked with a pencil and labelled. Capillary tube was used to spot the plates with the extract. Small quantities of the concentrated solutions were collected with capillary tube by dipping it in the solution. They were then used to spot the plates; three spots were made on each plate. Labelling of the samples was done with a pencil. The developing tank was prepare by measuring of $8 \mathrm{ml}$ ethyl acetate, $1 \mathrm{ml}$ formic acid and $1 \mathrm{ml}$ distilled water and poured into chromatotank. The plate were placed in chromatotank and covered, ensuring that the solvent was just below the spots. Apparatus was placed on a level surface for the solvent to rise. The plate was removed after about two hours when the solvent had risen close to the top edge, marking the distance travelled by solvent with a pencil. It was then dried at room temperature. The dried plate was then placed in a container, with iodine vapor to develop the spots on the plates. The spot moved by solvents and shape of spots were also marked out with a pencil. The distances moved by the solvents and the spots were measured. The retention factors of the samples were then determined. The retention factor, $\mathrm{R}$ means distance travelled by the compound divided by the distance travelled by the solvent. From these studies, it clearly indicates the presence of flavonoids (Fig.3).

Quantitative analysis of flavonoid:-

Total flavonoid content:-Standard flavonoid i.e. Gallic acid (1ug/ml), 2\% Aluminium chloride and Phosphate buffer saline was prepared. For determining the flavonoid content in the strain using gallic acid as standard and prepared the standard curve of Gallic acid with different concentrations and straight line was obtained. Using standard curve, determine total flavonoid content present in plant extract. Total flavonoid content in the strain determine through spectrophotometer at $420 \mathrm{~nm}$. Gallic acid used as standard $(\mu \mathrm{g} / \mathrm{ml})$ (Table 1).

\section{Microorganisms}

Ten bacterial strains obtained from the American Type Culture Collection (ATCC). They included gram-positive bacteria i.e. S. aureus, Enterococcus faecalis) and gramnegative bacteria i.e. P. aeruginosa, Escherichia coli, Salmonella typhi.

\section{Antimicrobial activity}

In this study, lysed virally infected human whole blood (100 $\mu \mathrm{l})$ were cultured with variable doses of flavonoids along with optimized dose of microorganism. Incubate the 96-well plates for $24 \mathrm{~h}$ at $37^{\circ} \mathrm{C}$. Add MTT $(5 \mathrm{mg} / \mathrm{ml}, 10 \mu \mathrm{l})$ solution, plates were suddenly centrifuged and discarding the supernatant. Finally dispersing in dimethyl sulphoxide (DMSO) solution. The optical density was measured at 570 $\mathrm{nm}[16]$.

\section{RESULTS AND DISCUSSION}

In the search for new immunopharmacological active compounds in the form of extracts (crude or fraction), mosses are considered as starting material with respect to secondary metabolites isolation and characterization, Its biological activity of mosses were compared with respect to known species of higher plants [14]. In this study, mosses were abundantly found in nature and easily cultivated. In this study, information from various sources were collected and showed some prophylactic and therapeutically potential for human diseases. 
Antibiotics are required for the therapy of various microbial (bacterial and fungal) infections. As per the literature, identification and discovery of these antibiotics from various sources and used them by medical practioners as chemotherapeutic agents [20]. So, these agents showing some relief to medical fraternity with respect to elimination of various infectious diseases. In this regard, continuous supply and urgently required to discover new type of antimicrobial compounds which showed diverse chemical structures [21, 22]. In the present scenario, emergence of multiple drug resistance related to human pathogenic organisms. Inspite of these, number of efforts were taken and search for new antimicrobial substances from other sources including plants as well. So, these plants are able to produce hundreds to thousands of diverse chemical compounds with different immunobiologically activities. In other words, antimicrobial compounds produced by plants are active against plant and human pathogenic microorganisms. It is expected that plant extracts showing target sites other than those used by antibiotics will be active against drug-resistant microbial pathogens [21-23].

Most of the bryophytes (e.g. mosses and bryophytes; nonvascular plants) are reported only in those areas where metal concentration is very high along with soil whose $\mathrm{pH}$ value is immoderate. As per the literature, completely absence of root system is reported in mosses but most of the water along with minerals which is generally absorbed by the entire body and their growth and development are readily affected through surrounding fluid conditions. In addition, 400 plant species are listed and is used for metal remediation. Out of these, 30 bryophytes (mosses and liverworts) are reported and demonstrated the use of bryophytes in phytoremediation. One of the species i.e. Funaria hygrometrica, moss is normally growing on metal-enriched substrates especially mine sites which is highly contaminated with copper, zinc, lead and other heavy metals. In this regard, studies were conducted related to Funaria hygrometrica and showed some ability related to metal tolerance including accumulation [24]. Normally, Funaria hygrometrica adsorbs $\mathrm{Pb}$ to extraordinary levels only when protonema (cellular localization, metal specificities, cell-wall components and effects of chemical factors) are exposed to solutions containing these ions [24]. From these studies suggested by Itouga et al which claimed that moss Funaria hygrometrica to mitigate $\mathrm{Pb}$ toxicity could help develop sustainable water cleaning systems [24].

In general, bryophytes are normally grown during unfavorable environment and it is considered as one of the earliest land plants and also be able to biosynthesize various secondary metabolites against biotic or abiotic stress. In addition, various secondary metabolites [14] isolated from various species of mosses and provide protection against microbial pathogens and also showed some specific function e.g. UV protection, drought tolerance, and freezing survival etc. In contrast, several constituents (isolated; characterized and investigated) isolated from moss species and showed several immunopharmacological properties e.g. antiinflammatory, antioxidant, anticancer activity etc. One of the most familiar example i.e. terpenoids and bibenzyls derivatives showed some potent candidate with respect to its cytotoxicity and is able to induce apoptosis through gene activation along with enzymes. In this regard, number of biochemical markers are involved i.e. DNA fragmentation, nuclear condensation, caspases activation along with inhibition of antiapoptotic nuclear transcriptional factorkappaB etc. and associated with apoptotic and necrotic response $[25,26]$.

Mosses in the form of peat mosses which is commonly used as biomonitors for determining the level of air pollution. With respect to its standardization related to monitoring of air quality where Sphagnum palustre was cultivated under sterile in vitro-conditions. Most of the clones exhibit acidbase properties which is totally similar to naturally-grown plants, whereas zinc adsorption is two-fold higher whereas $\mathrm{Cu} 2+$ adsorption is more efficient in peat mosses from nature. As in vitro-cultivated Sphagnum tissue has lower metal pollutant concentrations, it is suitable for biomonitoring [27].

Another studies were conducted in small and immobile moss i.e. Physcomitrella patens, where consumption of sunlight is required for this moss as one of its energy requirements. On the other hand, humans are somehow large and mobile but its energy is derived from vegetable or animal foods [28-29]. Lot of studies were conducted related to mammalian genes which were inserted into moss genome and should be easily to manufacture the proteins encoded therein. The major reason regarding sequences of plant, animal, fungi and bacterial genes which is considerably totally different but their proteins are produced and released from the cell in a right amount. Generally, biotechnologist should adapt this technique and tried to insert a foreign organism before transplanting a gene into it. Most of the researchers were totally astonished in order to find out the usage of moss which is not necessary [28, 29]. Recently, Physcomitrella patens manufacture or synthesize number of mammalian proteins which helped us pertaining to satisfy the worldwide demand related to therapeutic proteins [30]. The most familiar example is insulin, which enables diabetics to control their blood sugar level. According to the literature, therapeutic proteins are produced with in mammalian cells but it is very expensive with respect to cell culture. The major reason is to maintain the cells at body temperature with continuous supply of nutrients along with oxygen but its production process cost is very expensive [26-30]. In contrast, moss Physcomitrella patens, is totally undemanding and its major benefit to flourish large number of proteins 
only with the help of water, nutrient salts and light. So, it is very easy and convenient to handle this type of reaction related to mosses with in a bioreactor. In the future, less developed nations tried to satisfy their requirement with respect to therapeutic proteins [28-31]. Further immunobiologically research is required and applied for moss studies and is able to produce secondary metabolites especially flavonoids on an industrial scale.

The antimicrobial activity of Physcomitrella patens against some gram positive and gram negative bacteria has been shown in Table 1. One of the moss species i.e. Physcomitrella patens is able to inhibit both gram positive and gram-negative bacteria as well. As per the ecological point of view, presence of primary and secondary metabolites in mosses which is actively prevalent on Gramnegative bacteria which is further explained or confirmed through some strong competition existing between bryophytes, lacking anatomical barriers, and soil bacteria that are mostly Gram-negative. In other words, activity of such type of substances are useful for medical application with respect to gram positive and gram negative bacteria. As per the literature related to antibacterial activity of some mosses (especially Octoblepharum albidum, Hyophila involuta, $H$. perannulata, Campylopus introflexus, Syrrhopodon subconfertus, Erythrodontium julaceum and Sematophyllum subhumile) were collected from eastern Himalayas (different altitudes) in order to determine antioxidant (DPPH; 2, 2Diphenyle-1-pycril-hydrazyl hydrate)and antimicrobial potential for assessing its immunopharmacological importance as well. This antimicrobial study was tested on gram positive and gram negative bacteria as well i.e. Bacillus subtilis, Staphylococcus aureus, Escherichia coli and Klebsiella pneumoniae were used for experimentation and determined zone of Inhibition (ZOI) through agar well diffusion method. In this study, authors claimed that species of mosses showed some antioxidant and antimicrobial activity as well. In short, this study claimed that these mosses showed some therapeutic application against bacterial pathogens and also used for nutraceutical formulations.

\section{CONCLUSION AND FUTURE SCOPE}

The results from the present study demonstrated the presence of flavonoid content in strain of Physcomitrella patens. In this study, flavonoid content showed antimicrobial activity against gram positive and gram negative bacteria as well. The values of different concentration of flavonoid content which is present in the strain indicated its antimicrobial activity. In short, these results suggested that the levels of flavonoids contents varied not only from one strain to the other but also in their different parts tested. These results indicated that Physcomitrella patens showed antimicrobial activity because of flavonoids, which may be exploited for certain medicinal or pharmacological formulations.

Figures and Tables
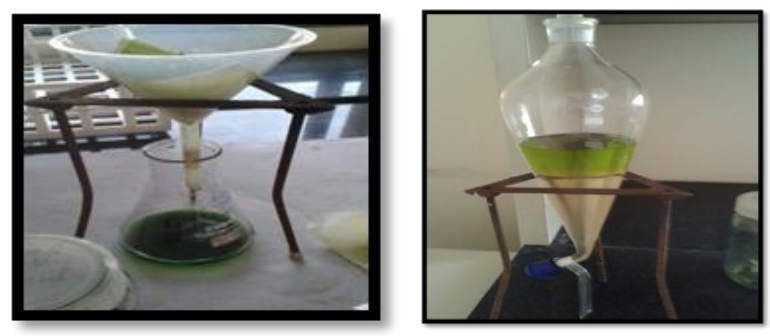

Fig.1. Extraction of flavonoid
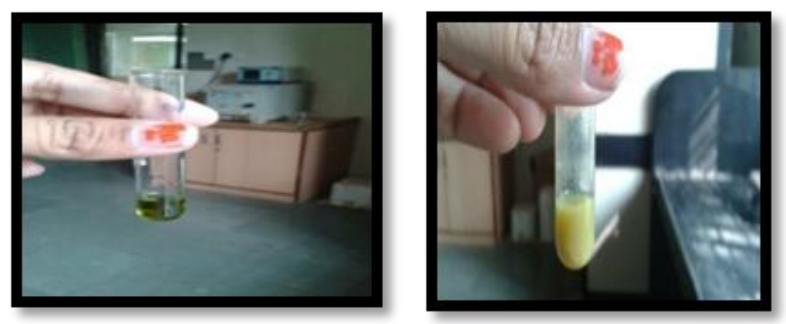

Fig.2. Qualitative analysis of flavonid
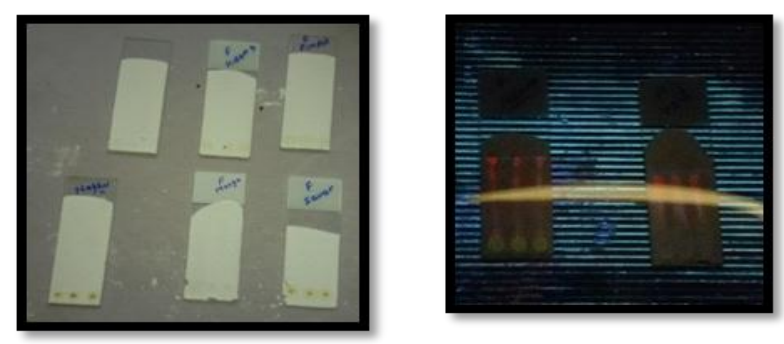

Fig.3. Confirmatory TLC picture of flavonoids

Table 1. Quantitative analysis of flavonoid

\begin{tabular}{|c|c|c|c|}
\hline \multirow[b]{2}{*}{$\begin{array}{c}\text { S. } \\
\text { No. }\end{array}$} & \multicolumn{3}{|c|}{ Table Column Head } \\
\hline & Plant name & $\begin{array}{l}\text { Lead } \\
\text { acetate } \\
\text { test }\end{array}$ & $\begin{array}{l}\text { Total } \\
\text { flavonoid } \\
\text { content } \\
\text { (ug/ml) }\end{array}$ \\
\hline 1 & $\begin{array}{c}\text { Protonemal tissue, } \\
\text { Strain of P. } \\
\text { Physcomitrella patens }\end{array}$ & + & 0.192 \\
\hline
\end{tabular}


Table 1. Effect of flavonoids from Protonemal tissue, Strain of P. Physcomitrella patens on gram positive and gram negative bacteria

\begin{tabular}{|c|c|c|c|c|}
\hline \multirow[t]{3}{*}{ Pathogens } & Samples & \multicolumn{3}{|c|}{$\begin{array}{l}\text { OD }(570 \mathrm{~nm}) \pm \mathrm{S} . \mathrm{E} . \\
\text { Flavonoids of strain }\end{array}$} \\
\hline & - & & $0.192 \mu \mathrm{g}$ & $0.384 \mu \mathrm{g}$ \\
\hline & Control & $0.008 \pm 0.0002$ & - & - \\
\hline \multirow[t]{3}{*}{ Gram positive bacteria } & S. aureus, $10 \mu \mathrm{g}$ & $0.348 \pm 0.06$ & $0.266 \pm 0.12$ & $0.124 \pm 0.02$ \\
\hline & Enterococcus faecalis, $10 \mu \mathrm{g}$ & $0.412 \pm 0.04$ & $0.382 \pm 0.08$ & $0.182 \pm 0.06$ \\
\hline & Control & $0.008 \pm 0.0002$ & - & - \\
\hline \multirow[t]{3}{*}{ Gram negative bacteria } & Escherichia coli, $10 \mu \mathrm{g}$ & $0.542 \pm 0.08$ & $0.368 \pm 0.16$ & $0.258 \pm 0.04$ \\
\hline & Salmonella typhi, $10 \mu \mathrm{g}$ & $0.502 \pm 0.12$ & $0.488 \pm 0.18$ & $0.374 \pm 0.14$ \\
\hline & P. aeruginosa, $10 \mu \mathrm{g}$ & $0.644 \pm 0.18$ & $0.508 \pm 0.12$ & $0.298 \pm 0.16$ \\
\hline
\end{tabular}

\section{REFERENCES}

[1]. M. Konrat, A.J. Shaw, K.S. Renzaglia, "A special issue of Phytotaxa dedicated to Bryophytes: The closest living relatives of early land plants" Phytotaxa, Vol, 9, pp. 5-10, 2010.

[2]. P. Kenrick, P.R. Crane, "The origin and early evolution of plants on land, Nature, Vol 389, S. No. 6646, pp. 33-39, 1997.

[3]. E.L. Decker, R. Reski, "Moss bioreactors producing improved biopharmaceuticals, " Current Opinion in Biotechnology, Vol. 18, S. No. 5, pp. 393-398, 2007.

[4]. R. Mishra, V.K. Pandey, R. Chandra, "Potential of bryophytes as therapeutics," International journal of pharmaceutical sciences and research, Vol. 3, pp. 3584-3593, 2014.

[5]. D.J. Cove, C.D. Knight, T. Lamparter, "Mosses as model systems," Trends Plant Science, Vol. 2, pp. 99-105, 1997.

[6]. W.O. Abel, W. Knebel, H.U. Koop, J.R. Marienfeld, H. Quader, R. Reski, E. Schnepf, B. Spörlein, "A cytokininsensitive mutant of the moss, Physcomitrella patens, defective in chloroplast division," Protoplasma, Vol. 152, pp. 1-13, 1989.

[7]. Y. Hiwatashi, T. Nishiyama, F. Tomomichi, M. Hasebe, "Establishment of gene-trap and enhancer-trap in the moss Physcomitrella patens," Plant Journal, Vol. 28, pp. 105-116, 2001.

[8]. N.T. Krogan, N.W. Ashton, "Ancestry of plant MADS box genes revealed by bryophyte (Physcomitrella patens) homologues, ” New Phytol, Vol. 147, pp. 505-517, 2000.

[9]. R. Reski, J. Parsons, E.L. Decker, "Moss-made pharmaceuticals: from bench to bedside," Plant Biotechnology Journal, Vol. 13, pp. 1191-1198, 2015.

[10]. D. Lang, A.D. Zimmer, S.A. Rensing, R. Reski, "Exploring plant biodiversity: the Physcomitrella genome and beyond," Trends in Plant Science, Vol. 13, pp. 542-549, 2008.

[11]. M. Hubers, H. Kerp. Oldest known mosses discovered in Mississippian (late Visean) strata of Germany. Geology, Vol. 40, S.No. 8, pp. 755-758, 2012.

[12]. R. Reski, W. Frank, "Moss (Physcomitrella patens) functional genomics - Gene discovery and tool development with implications for crop plants and human health," Briefings in Functional Genomics and Proteomics, Vol. 4, pp. 48-57, 2005.

[13]. D.T. Hanson, S.K. Rice, "Photosynthesis in Bryophytes and Early Land Plants," Springer, Vol. 37; S.No. 8, 2014.

[14]. C.F. Xie, H.X. Lou, "Secondary metabolites in bryophytes: an ecological aspect," Chem Biodivers, Vol. 6, S. No. 3, pp. 303312, 2009.
[15]. X. Wang, J. Cao, X. Dai, J. Xiao, Y. Wu, Q. Wang, "Total flavonoid concentrations of bryophytes from Tianmu Mountain, Zhejiang Province (China): Phylogeny and ecological factors, "' PLOS ONE, Vol. 12, S. No. 6, pp. e0179837, 2017.

[16]. A. Gupta, S.R. Chaphalkar, "Immunopharmacological activity of flavonoids isolated from Mesua ferrea, Ficus benghalensis and Jasminum auriculatum," Current Life Sciences, Vol. 2, S.No.2, pp. 49-54, 2016.

[17]. M. Ali, V. Agrawal, "Thin-layer chromatography of aromatic amines," Separation Science and Technology, Vol. 37, pp. 363 $-377,2002$.

[18]. S. Singhal, N. Singhal, S. Agarwal, "Pharmaceutical Analysis II, Thin layer chromatography," Pragati prakashan First edition, pp 98-111, 2009.

[19]. M. Khurram et al, "Evaluation of anticandidal potential of Quercus baloot Griff. Using contact bioautography technique," Afr J Pharm Pharmacol, Vol. 5, S.No. 12, pp. $1538-1542,2012$.

[20]. S.G. Ciancio, "Antiseptics and antibiotics as chemotherapeutic agents for periodontitis management," Compend Contin Educ Dent, Vol. 21, S. No. 1, pp. 59-62, 2000.

[21]. A.E. Allsop, "New antibiotic discovery, novel screens, novel targets and impact of microbial genomics," Curr Opin Microbiol, Vol. 1, pp. 530-534, 1998.

[22]. M.R. Barbachyn, E.M. John, "Recent advances in the discovery of hybrid antibacterial agents," Annu Rep Med Chem, Vol. 43, pp. 281-290, 2008.

[23]. J.J. Barker, "Antibacterial drug discovery and structure-based design," Drug Discov Today, Vol. 11, pp. 391 - 404, 2006.

[24]. M. Itouga, M. Hayatsu, M. Sato, Y. Tsuboi, Y. Kato, K. Toyooka et al, "Protonema of the moss Funaria hygrometrica can function as a lead $(\mathrm{Pb})$ adsorbent," PLoS ONE, Vol. 12, S. No. 12, pp. e0189726, 2017.

[25]. S. Friederich, U.H. Maier, B. Deus-Neumann, "Biosynthesis of cyclic bis (bibenzyls) in Marchantia polymorpha," Phytochemistry, Vol. 50, pp. 589-598, 1999.

[26]. M. Singh, R. Govindarajan, V. Nath, A.K.S. Rawat, S. Mehrotra, "Antimicrobial, wound healing and antioxidant activity of Plagiochasma appendiculatum, Journal of Ethnopharmacology, Vol. 107, S. No. 1, pp. 67-72, 2006.

[27]. K. Szczepaniak, A. Astel, V. Simeonov S. Tsakovski, M. Biziuk, P. Bode, A. Przyjazny, "Comparison of dry and living Sphagnum palustre moss samples in determining their biocumulative capability as biomonitoring tools," J Environ Sci Health A Tox Hazard Subst Environ Eng, Vol. 42, S.No. 8, pp. 1101-1115, 2007 
[28]. D.G. Schaefer, J.P. Zryd, "Efficient gene targeting in the moss Physcomitrella patens," Plant Journal, Vol. 11, S. No. 6, pp. 1195-1206, 1997.

[29]. D.G. Schaefer, "A new moss genetics: targeted mutagenesis in Physcomitrella patens, "Annual Review of Plant Biology, 53, 477-501, 2002.

[30]. E.L. Decker, R. Reski, "Moss bioreactors producing improved biopharmaceuticals," Current Opinion in Biotechnology, Vol. 18, S. No. 5, pp. 393-398, 2007.

[31]. Gitzinger et al, "Functional cross-kingdom conservation of mammalian and moss (Physcomitrella patens) transcription, translation and secretion machineries,". Plant Biotechnology Journal, Vol. 7, S. No. 1, pp. 73, 2009.

[32]. Maddi R, Kandula LV, Vallepu B, Navuluri H, Kollu H, "Preliminary Phytochemical Analysis and Invitro Anti-viral Activity of Ethanolic extract of Whole plant of Tinospora cordifolia (Thunb.) Miers against Hepatitis-A Virus," International Journal of Scientific research in biological Sciences, Vol.5 , Issue 3, pp.51-55, 2018

\section{AUTHORS PROFILE}

Dr Amit Gupta currently working as Assistant Professor in School of Sciences from P.P. Savani University since 2017. $\mathrm{He}$ has published numerous research papers in reputed international journals including Thomson Reuters (SCI \& Web of Science). His main research work focuses on Immunopharmacology. He has 7 years of teaching experience and 10 years of research experience. In addition, Sumesh Shah, Masters in Microbiology and one year industrial experience whereas Gazala G. Saiyed, S.A. Pathan, Hanifa F. Dudha, S.S. Das, students of B.Sc. Biotechnology/Microbiology in P.P. Savani University. S. Palekar, MD Microbiology recently working in Mrinmay diagnostic lab (MDL), Shaupuri Vyaparipeth Suvarna Hospital, Kolhapur 